\title{
Syn- and post-tectonic cooling and exhumation in the Larsemann Hills, East Antarctica
}

\author{
1. Institute of Geology, Chinese Academy of Geological Sciences, Baiwanzhuang Rd., Beijing 100037 \\ 2. Institute of Geology, Chinese Academy of Sciences, Dewai, Beijing 100029 \\ 3. Institute of High Energy Physics, Chinese Academy of Sciences, Zhongguancun, Beijing 100080
}

In this paper, we present ${ }^{40} \mathrm{Ar} /{ }^{39} \mathrm{Ar}$ hornblende, biotite, and $K$-feldspar and apatite fission track thermochronological data to constrain the cooling and exhumation of high-grade rocks of the Larsemann Hills, Antarctica, synchronous with and postdated regional intense orogenesis of the early Paleozoic. Combined with $\mathrm{Pb}-\mathrm{Pb}$, $U-P b, S m-N d$ and ${ }^{40} A r{ }^{39} \mathrm{Ar}$ age data published, a ${ }^{40} \mathrm{Ar}{ }^{39} \mathrm{Ar}$ plateau age of hornblende recorded cooling below c. $520^{\circ} \mathrm{C}$ at $514 \pm 2 \mathrm{Ma}$ at a rate of c. $40^{\circ} \mathrm{C} / \mathrm{Ma}$. This rapid cooling can be attributed to the tectonically driven exhumation along the ductile shear zoons. By $514 \mathrm{Ma}, \mathrm{c.10-15} \mathrm{km}$ of exhumation had achieved. Slowing of the cooling rate from $\mathrm{c} .9^{\circ} \mathrm{C} / \mathrm{Ma}$ to c. $3^{\circ} \mathrm{C} / \mathrm{Ma}$ occurred during $500-490 \mathrm{Ma}$, when the geotherm dropped through the closure temperature for ${ }^{40} \mathrm{Ar} /{ }^{39} \mathrm{Ar}$ system in biotite at c. $300^{\circ} \mathrm{C}$. Documented by an ${ }^{40} \mathrm{Ar} \mathrm{H}^{39} \mathrm{Ar}$ plateau age of $\mathrm{K}$-feldspar, further drop of the geotherm below c. $160^{\circ} \mathrm{C}$ took place around $455 \mathrm{Ma}$, by which erosionally controlled exhumation had become dominant, as suggested by the very slow cooling rate at c. 3-0.3 ${ }^{\circ} \mathrm{C} / \mathrm{Ma}$. The final cooling through apatite partial annealing zone happened at c. $210 \mathrm{Ma}$ and could correspond to an early period of aborted rifting in the Lambert Garben region.

\section{Introduction}

The Larsemann Hills region, located on the Ingrid Christensen Coast of Prydz Bay (Figure 1a), East Antarctica, was once considered as part of an extensive Mesoproterozoic (c. $1000 \mathrm{Ma}$ ) high-grade terrane that extends over much of the East Antarctic Craton (e.g. Sheraton et al., 1984; Stüwe et al., 1989). The notion was first challenged by the studies of the high-grade rocks of the Larsemann Hills (Zhao et al., 1991, 1992; Ren et al., 1992; Zhou and Hensen, 1992; Dirks et al., 1993). Increasing evidence from chronological data (Zhao et al., 1992, 1993; Kinny et al., 1993; Hensen and Zhou, 1995; Zhang et al., 1996; Carson et al., 1996; Fitzsimons et al., 1997), structural analyses (Dirks et al., 1993; Dirks and Wilson, 1995; Carson et al., 1995), textural information and P-T condition estimates (Stüwe and Powell, 1989a; Ren et al., 1992; Fitzsimons, 1996; Carson et al., 1997) has verified that it is the Early Paleozoic orogenesis, rather than a Mesoproterozoic tectonothermal event, that contributed to the tectonic evolution of the Larsemann Hills and adjacent regions. However syn- and post-tectonic cooling and exhumation was poorly constrained by thermochronological data. This paper presents ${ }^{40} \mathrm{Ar} /{ }^{39} \mathrm{Ar}$ hornblende, biotite, and $\mathrm{K}$-feldspar and apatite fission track thermochronological data, combined with $\mathrm{Pb}-\mathrm{Pb}, \mathrm{U}-\mathrm{Pb}, \mathrm{Sm}-$ $\mathrm{Nd}$ and ${ }^{40} \mathrm{Ar} /{ }^{39} \mathrm{Ar}$ age results published, to expound this problem.

\section{Geological background and previous geochronology}

The bedrocks in the Larsemann Hills consist predominantly of pelitic, psammitic and felsic paragneisses metamorphosed to peak condition of c. $7 \mathrm{kbar}$ at c. $800{ }^{\circ} \mathrm{C}$ (Carson et al., 1997) and small peraluminous granite bodies and pegmatite dykes with various degrees of deformation (Stüwe et al., 1989; Dirks et al., 1993; Zhao et al., 1995; Carson et al., 1995). Decompression from the peak condition to c. $4.5 \mathrm{kbar}$ at $750^{\circ} \mathrm{C}$ dominated the high-grade retrograde evolution of the region (Stüwe and Powell, 1989; Ren et al., 1992; Fitzsimons, 1996; Carson et al., 1997). The Sm-Nd model ages $\left(T_{D M}\right)$ range from 2200-700 $\mathrm{Ma}$ (Sheraton et al., 1984; Hensen and Zhou, 1995; Zhao et al., 1995) for the gneisses and partial melting bodies of the Larsemann Hills and adjacent regions, much diffent from those of the Archean Vestfold Hills Block (Figure la), which has formed and metamorphosed around 2500 Ma (Black et al., 1991), and southern Rauer Islands gneisses with Archean components (Sheraton et al., 1984; Kinny et al., 1993). Intense Pan-African tectonism in Prydz Bay has been demonstrated by $\mathrm{Pb}-\mathrm{Pb}$ zircon evaporation ages of $547 \pm 9 \mathrm{Ma}$ and $556 \pm 7 \mathrm{Ma}$ (Zhao et al., 1992) and SHRIMP U-Pb zircon ages of $516 \pm 7 \mathrm{Ma}$ and $514 \pm 7 \mathrm{Ma}$ for the syntectonic Progress Granite (Carson et al., 1996), U-Pb monazite ages of $541 \pm 1 \mathrm{Ma}$ and $527 \pm 1$ Ma for paragneisses (Zhang et al., 1996) and SHRIMP U-Pb zircon ages of $535 \pm 13 \mathrm{Ma}$ and $536 \pm 35 \mathrm{Ma}$ and monazite ages of $528 \pm 4,527 \pm 11,518 \pm 3$ and $512 \pm 13$ Ma for anatectic leucogneiss (Fitzismons et al., 1997) and $\mathrm{Pb}-\mathrm{Pb}$ zircon evaporation ages and SHRIMP U-Pb zircon ages of 600-500 Ma for migmatitic paragneisses (Zhao et al., 1993, unpublished data, 1997), garnet-whole-rock Sm-Nd dates of 517-467 Ma for various gneisses (Zhao et al., 1993; Hensen and Zhou, 1995b). A poorly defined Rb$\mathrm{Sr}$ isochron of $560 \pm 70 \mathrm{Ma}$ for the paragneisses (Sheraton et al., 1984), previously regarded as a low-to medium-grade metamorphic overprint associated with the emplacement of granite bodies (e.g. the $500 \mathrm{Ma}$ Landing Bluff Granite, Tingey, 1991), is attributed to the intense Early Paleozoic tectonothermal activities. A model of compressional $\left(D_{2}\right)$ and extensional ( $D_{3}$ ) orogenesis has been proposed for Early Paleozoic tectonism (Carson et al., 1995; Dirks and Wilson, 1995). The emplacement of late planar pegmatite dykes in the Rauer Islands at $500 \pm 12 \mathrm{Ma}$ (Kinny et al., 1993), ${ }^{40} \mathrm{Ar} /{ }^{39} \mathrm{Ar}$ biotite ages of 500-486 Ma for migmatitic paragneisses, syntectonic granite and pegmatite (Zhao et al..1992,1993; Fu et al., 1993) as well as an ${ }^{40} \mathrm{Ar} /{ }^{39} \mathrm{Ar}$ whole-rock age of $443 \pm 3$ Ma for migmatite (Takigami et al., 1992), which are similar with previously reported $\mathrm{K}$-Ar ages of $405 \mathrm{Ma}$ and $504 \mathrm{Ma}$ for the metamorphic rocks from the regions (Picciotto and Coppez, 1963; Ravich et al., 1965), show that the 


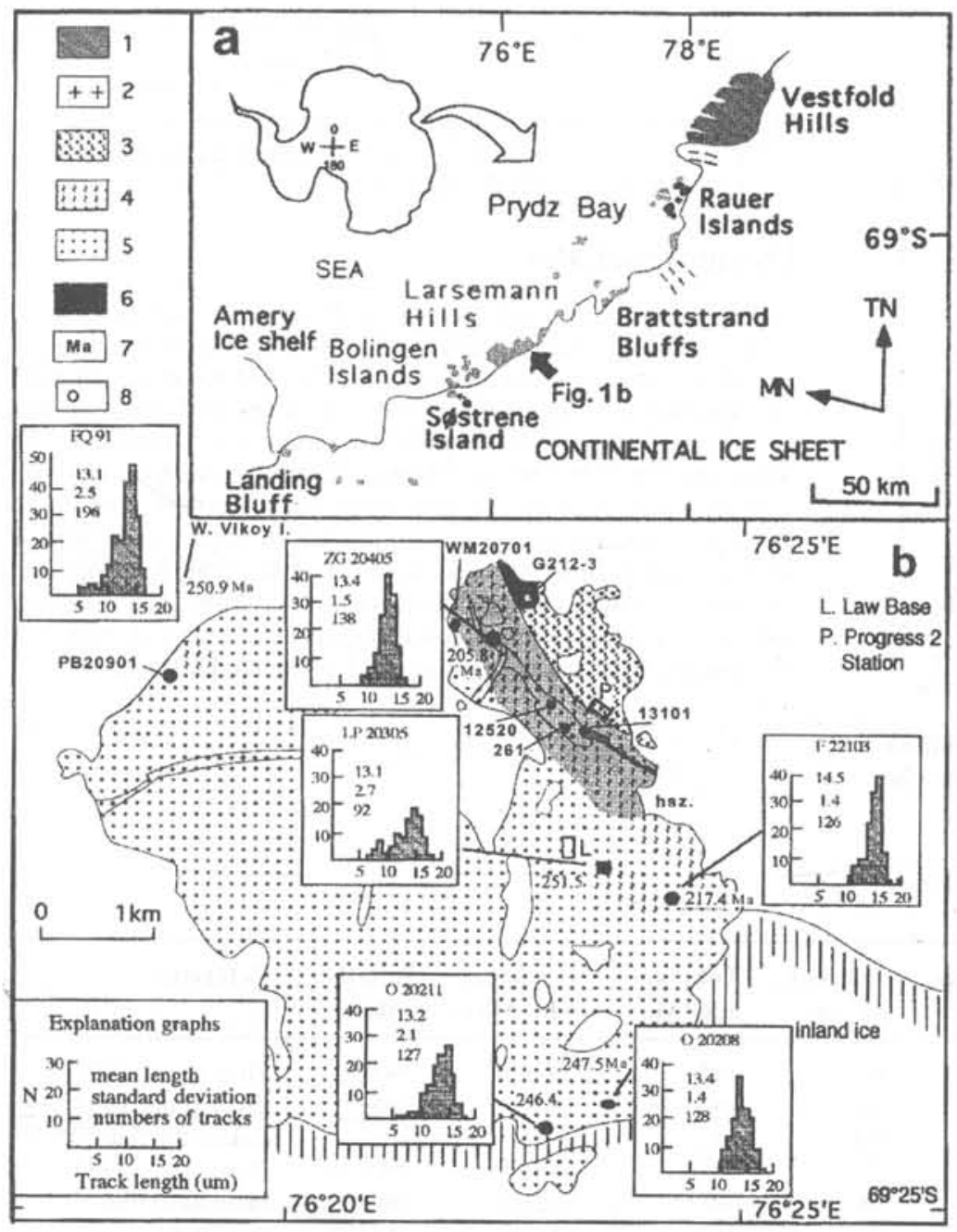

Figure 1 Map showing location of the Larsemann Hill and adjacent regions, Prydz Bay, East Antarctica (a), and sampling localities in the eastern Larsemann Hills, with apatite f-t ages and track length distributions for the samples (b). (1) Granite-pegmatite, (2) Syenogranite, (3) Gneissic leucogranite (4) High-Al-Fe-Mg-gneisses, (5) Migmatitic paragneiss, (6) Mafic gneiss, (7) Apatite f-t age, (8) Sampling locality hsz.: high strain zone.

high-grade terranes on the Ingrid Christensen Coast were cooling around $500 \mathrm{Ma}$. However, the low and medium termperature thermochronological data are still required to constrain on cooling and exhumation of the granulite terrane, although apatite fission track data from areas adjoining the Larsemann Hills region indicated cooling through temperatures below c. $100^{\circ} \mathrm{C}$ between about $300 \mathrm{Ma}$ and $200 \mathrm{Ma}$ (Arne et al., 1993).

\section{${ }^{40} \mathrm{Ar} /{ }^{39} \mathrm{Ar}$ and apatite fission track analyses}

\section{Samples}

The sampling locations are indicated in Figure $1 \mathrm{~b}$. The ${ }^{40} \mathrm{Ar} /{ }^{39} \mathrm{Ar}$ samples were described for Sm-Nd analyses (Zhao et al., 1993, 1995), and two of the fission track samples (ZG20405 and F22103) were described for zircon $\mathrm{Pb}-\mathrm{Pb}$ dating (Zhao et al., 1992, 1995). Brief descriptions of the rest of fission track samples are given here.

FQ91, from southwestern Vikoy Island about $1 \mathrm{~km}$ north of Broknes Peninsula, is a medium- to coarse-grained cordierite-magnetite gneiss. LP20305, from a locality just southeast of the Aus- tralian Law Base, is a fine- to medium-grained garnet sillimanite gneiss. O20211, from the southernmost Mirror Peninsula, is a fine- to medium-grained biotite-garnet gneiss. O20208, about $700 \mathrm{~m}$ northeast of O20211, is also a fine- to medium-grained biotite-garnet gneiss.

Mineral concentrates were extracted using standard procedures including the Wilfley table, magnetic and heavy-liquid separation techniques. All minerals were finally purified by hand-picking under a binocular microscope. The grain radii of hornblende, biotite and $\mathrm{K}$ feldspar for ${ }^{{ }^{10}} \mathrm{Ar} /{ }^{39} \mathrm{Ar}$ analyses, including biotites previously dated, are generally larger than $1 \mathrm{~mm}$.

\section{Experimental procedures}

The ${ }^{40} \mathrm{Ar} /{ }^{39} \mathrm{Ar}$ analysis was performed on a MM-1200 mass spectrometer in the Laboratory of Isotope Geochronology, Institute of Geology, Chinese Academy of Geological Sciences. The samples were irradiated in the core of the facility $\mathrm{H}_{4}$ of 49-2 reactor in Chinese Academy of Atomic Energy Science. The standard biotite $\mathrm{ZBH}-25$ ( $133.5 \mathrm{Ma}$ ) was used as the "flux monitor". ${ }^{40} \mathrm{Ar} /{ }^{39} \mathrm{Ar}$ ages were calculated by using the following constants, $\lambda_{\varepsilon}=0.581 \times 10^{-10} \mathrm{y}^{-1}, \lambda_{\beta}=4.962 \times 10^{-10} \mathrm{y}^{-1}$ (Steiger and Jäger, 1977). The experimental precedure was described by Fu et al. (1987). All errors quoted in Table 1 and Figure 2 are on $1 \sigma$ basis.

Apatite fission track analysis was carried out in the Laboratory of the Nucleus Analysis Technique, Institute of High Energy Physics, Chinese Academy of Sciences. The procedure was outlined by Kang et al. (1990). Apatite ages were determined using the external detector method. Standard and induced track densities were measured on muscovite external detectors and fossil track densities on internal mineral surfaces. Thermal neutron fluences were monitored using NBS standard glass SRM 962. The samples were irradiated in the facility A of the heavy water reactor in Chinese Academy of Atomic Energy Science. Ages were calculated using the zeta calibration method following the procedures of Hurford and Green (1983). Errors were calculated using the method described by Naeser (1978). Their uncertainties quoted in Table 2 are at the $I \sigma$ level. Track lengths were measured in apatite grains on horizontal confined fission tracks.

\section{The ${ }^{40} \mathrm{Ar} /{ }^{39} \mathrm{Ar}$ Data}

${ }^{40} \mathrm{Ar} /{ }^{39} \mathrm{Ar}$ age spectra for hornblende, biotite and $\mathrm{K}$-feldspar are shown in Figure 2, and the ${ }^{40} \mathrm{Ar} /{ }^{39} \mathrm{Ar}$ results are summarized in Table 1, with biotite and whole-rock ${ }^{40} \mathrm{Ar} /{ }^{39} \mathrm{Ar}$ results published.

Hornblende from the mafic granulite (Sample G212-3) yielded concordant plateau and isochron ages (Table 1). The plateau age for steps $4-7$, accounting for $87 \%$ of the ${ }^{39} \mathrm{Ar}$ released, is $514 \pm 2 \mathrm{Ma}$, the corresponding isochron age is $515 \pm 5 \mathrm{Ma}$, with an initial ${ }^{40} \mathrm{Ar} /{ }^{36} \mathrm{Ar}$ ratio of $303 \pm 59$

Biotite from the greyish-white biotite gneiss on northern Broknes Peninsula (Sample BP20901) gave a well-defined plateau age of $506 \pm 2 \mathrm{Ma}$, for which radiogenic products are $84 \%$. The isochron age for this sample, based on steps $5-8$, is $506 \pm 5 \mathrm{Ma}$, with an initial ${ }^{40} \mathrm{Ar} /{ }^{36} \mathrm{Ar}$ ratio of $303 \pm 68$.

$\mathrm{K}$-feldspar was analyzed from a migmatitic paragneiss (Sample F22103), which is lithologically identical to a coarse-grained garnetbearing leucosome with garnet segregations forming the cores and $\mathrm{K}$-feldspar making up the mantles described by Stüwe and Powell (1989b). K-feldspar yielded concordant age spectra with a plateau age of $455 \pm 4$ Ma for steps $6-9$ (71\% of the ${ }^{39} \mathrm{Ar}$ released). The isochron age for this sample is $451 \pm 5 \mathrm{Ma}$, with an initial ${ }^{40} \mathrm{Ar} /{ }^{36} \mathrm{Ar}$ ratio of $288 \pm 78$. Step 8 is slightly older $(460 \pm 4 \mathrm{Ma})$. Without steps 8 and 10 , the rest of 8 factions gave a mean age of $449 \pm 4 \mathrm{Ma}$, similar 


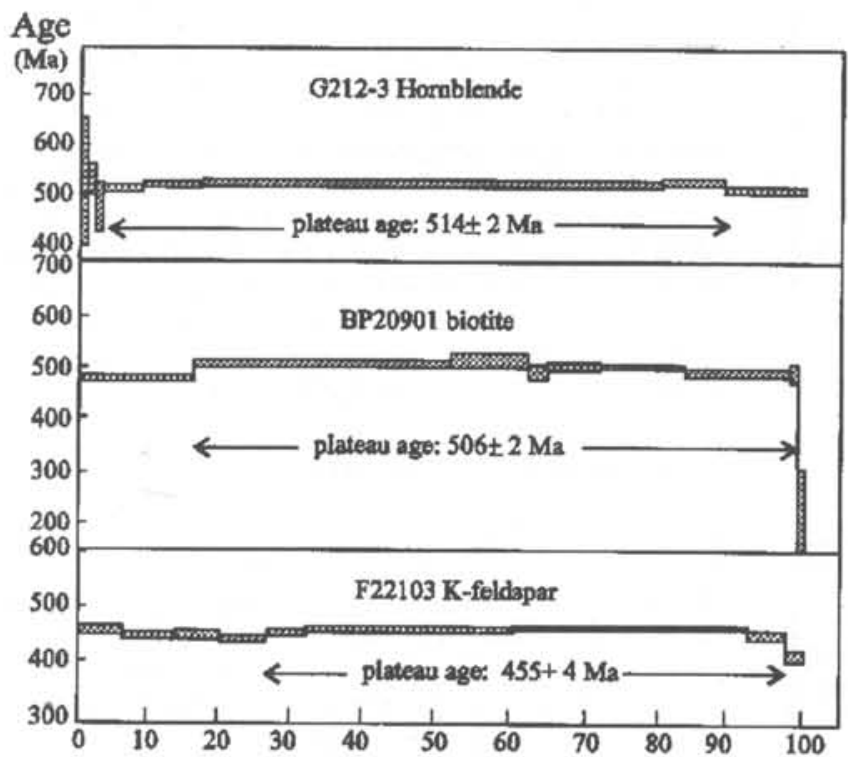

Figure 2 Age spectra for ${ }^{40} \mathrm{Ar} /{ }^{39} \mathrm{Ar}$ samples from the Larsemann Hills, East Antarctica, (a) hornblende (G212-3), (b) biotite (BP20901), (c) K-feldspar (F22103).

Table 1 Summary of ${ }^{40} \mathrm{Ar} /{ }^{39} \mathrm{Ar}$ results of the Larsemann Hills to ${ }^{40} \mathrm{Ar} /{ }^{39} \mathrm{Ar}$ plateau age of $443 \pm 3 \mathrm{Ma}$ for the whole-rock sample (A316), whose main component is $\mathrm{K}$-feldspar.

The closure temperatures ( $\mathrm{T} c$ ) of ${ }^{40} \mathrm{Ar} /{ }^{39} \mathrm{Ar}$ system in hornblende, biotite and $\mathrm{K}$-feldspar adopted in this study are c. $520^{\circ} \mathrm{C}$, c. $300^{\circ} \mathrm{C}$ and c. $160^{\circ} \mathrm{C}$ respectively, with reference to the data summarized by McDougall and Harrison (1988).

\section{Fission Track Data}

Apatite fission track data are tabulated (Table 2), and fission track cooling ages and track length distributions are illustrated in Figure 1b. All the apatite fission track ages have passed the $\chi^{2}$ test, and they are significantly yourger than ${ }^{40} \mathrm{Ar} /{ }^{39} \mathrm{Ar}$ dates of $\mathrm{K}$-feldspar from Sample F22103 and the whole-rock sample (A316) nearby. The dates range from $252 \mathrm{Ma}$ to $206 \mathrm{Ma}$. The samples with the oldest fission track ages have the shortest mean track length of $13.1 \mu \mathrm{m}$ and the largest standard deviations from $2.7 \mu \mathrm{m}$ to $2.5 \mu \mathrm{m}$, while samples with younger fission track ages have longer mean track lengths up to $14.5 \mu \mathrm{m}$ and lower standard deviations, $1.4-2.1 \mu \mathrm{m}$. The results are generally in agreement with those obtained by Arne et al. (1993) for the samples from areas adjoining the Larsemann Hills region.

\begin{tabular}{|c|c|c|c|c|c|c|c|c|c|}
\hline Sample & Rock type & Mineral & $\begin{array}{l}\text { Plateau } \\
\text { age (Ma) }\end{array}$ & Steps & $\begin{array}{l}\text { Percent } \\
\text { of gas }\end{array}$ & $\begin{array}{l}\text { Total gas } \\
\text { age (Ma) }\end{array}$ & $\begin{array}{l}\text { Isochron } \\
\text { age (Ma) }\end{array}$ & $\begin{array}{l}\text { Initial } \\
\text { ratio }\end{array}$ & Reference \\
\hline 12520 & syenogranite & biotite & $494 \pm 1$ & $2-8$ & 91 & 491 & $495 \pm 5$ & $292 \pm 4$ & Zhao et al., 1992 \\
\hline 13101 & pegmatite & biotite & $486 \pm 1$ & $2-8$ & 93 & 483 & $486 \pm 4$ & $295 \pm 2$ & Zhao et al., 1992 \\
\hline A 316 & migmatite & whole-rock & $443 \pm 3$ & $3-8$ & 94 & 447 & & & Takigami et al., 1992 \\
\hline WM20701 & paragneiss & biotite & $488 \pm 2$ & $3-7$ & 72 & 487 & $486 \pm 7$ & $290 \pm 38$ & Zhao et al., 1993 \\
\hline \multirow[t]{2}{*}{ F22103 } & migmatitic & biotite & $500 \pm 4$ & $2-8$ & 96 & 498 & $502 \pm 7$ & $289 \pm 13$ & \multirow{2}{*}{$\begin{array}{l}\text { Fu et al., } 1993 * \\
\text { this study }\end{array}$} \\
\hline & paragneiss & K-feldspar & $\begin{array}{l}455 \pm 4 \\
(449 \pm 4)\end{array}$ & $\begin{array}{l}6-9 \\
1-7,9\end{array}$ & 71 & 453 & $451 \pm 5$ & $287 \pm 78$ & \\
\hline \multirow[t]{2}{*}{ BP20901 } & gneiss & biotite & $506 \pm 2$ & $2-8$ & 84 & 501 & & & \multirow[t]{2}{*}{ this study } \\
\hline & & & $507 \pm 1$ & $5-8$ & & & $506 \pm 5$ & $303 \pm 68$ & \\
\hline G212-3 & $\begin{array}{l}\text { mafic } \\
\text { granulite }\end{array}$ & hornblende & $514 \pm 2$ & $4-7$ & 87 & 514 & $515 \pm 5$ & $303 \pm 59$ & this study \\
\hline
\end{tabular}

*: Recalculated by this study, mean ages reported in parentheses, $1 \sigma$ intralaboratory errors.

Table 2 Apatite fission track data of the eastern Larsemann Hills

\begin{tabular}{|c|c|c|c|c|c|c|c|c|c|c|}
\hline Sample & $\begin{array}{l}\text { Elevation } \\
\text { (m) }\end{array}$ & $\begin{array}{l}\text { Number } \\
\text { of grains }\end{array}$ & $\begin{array}{l}\text { Fluence } \\
\left(10^{15} / \mathrm{cm}^{-2}\right)\end{array}$ & $\begin{array}{l}\rho_{\mathrm{s}} \\
\left(10^{5} / \mathrm{cm}^{2}\right)\end{array}$ & $\begin{array}{l}\rho_{i} \\
\left(10^{5} / \mathrm{cm}^{2}\right)\end{array}$ & $\mathbf{r}$ & $\begin{array}{l}\mathbf{P}\left(\mathbf{x}^{2}\right) \\
\%\end{array}$ & $\begin{array}{l}\text { FT-age } \\
\text { (Ma) }\end{array}$ & $\begin{array}{l}\text { Mean track } \\
\text { length }(\mu \mathrm{m})\end{array}$ & $\begin{array}{l}\text { Standard } \\
\text { deviation }(\mu \mathrm{m})\end{array}$ \\
\hline ZG20405 & 22 & 9 & 5.132 & $\begin{array}{l}6.692 \\
(1835)\end{array}$ & $\begin{array}{l}4.916 \\
(1348)\end{array}$ & 0.988 & 70 & $206 \pm 4$ & $\begin{array}{l}13.4 \\
(138)\end{array}$ & 1.5 \\
\hline F22103 & 97 & 20 & 5.132 & $\begin{array}{l}4.982 \\
(992)\end{array}$ & $\begin{array}{l}3.461 \\
(689)\end{array}$ & 0.974 & 50 & $217 \pm 4$ & $\begin{array}{l}14.5 \\
(126)\end{array}$ & 1.4 \\
\hline O20208 & 126 & 16 & 6.172 & $\begin{array}{l}48.33 \\
(2733)\end{array}$ & $\begin{array}{l}35.38 \\
(2001)\end{array}$ & 0.989 & 70 & $248 \pm 4$ & $\begin{array}{l}13.7 \\
(128)\end{array}$ & 1.7 \\
\hline O20211 & 135 & 7 & 6.531 & $\begin{array}{l}38.75 \\
(992)\end{array}$ & $\begin{array}{l}30.16 \\
(772)\end{array}$ & 0.999 & 95 & $246 \pm 4$ & $\begin{array}{l}13.2 \\
(127)\end{array}$ & 2.1 \\
\hline LP20305 & 82 & 13 & 6.172 & $\begin{array}{l}17.69 \\
(1824)\end{array}$ & $\begin{array}{l}12.74 \\
(1314)\end{array}$ & 0.989 & 95 & $252 \pm 5$ & $\begin{array}{l}13.1 \\
(92)\end{array}$ & 2.7 \\
\hline FQ91 & 7 & 12 & 6.172 & $\begin{array}{l}24.25 \\
(1421)\end{array}$ & $\begin{array}{l}17.51 \\
(1026)\end{array}$ & 0.975 & 90 & $251 \pm 5$ & $\begin{array}{l}13.1 \\
(196)\end{array}$ & 2.5 \\
\hline
\end{tabular}

The number of tracks counted (age data) or measured (lengths) is given in parentheses, uncertainties given at the $1 \sigma$ level. 


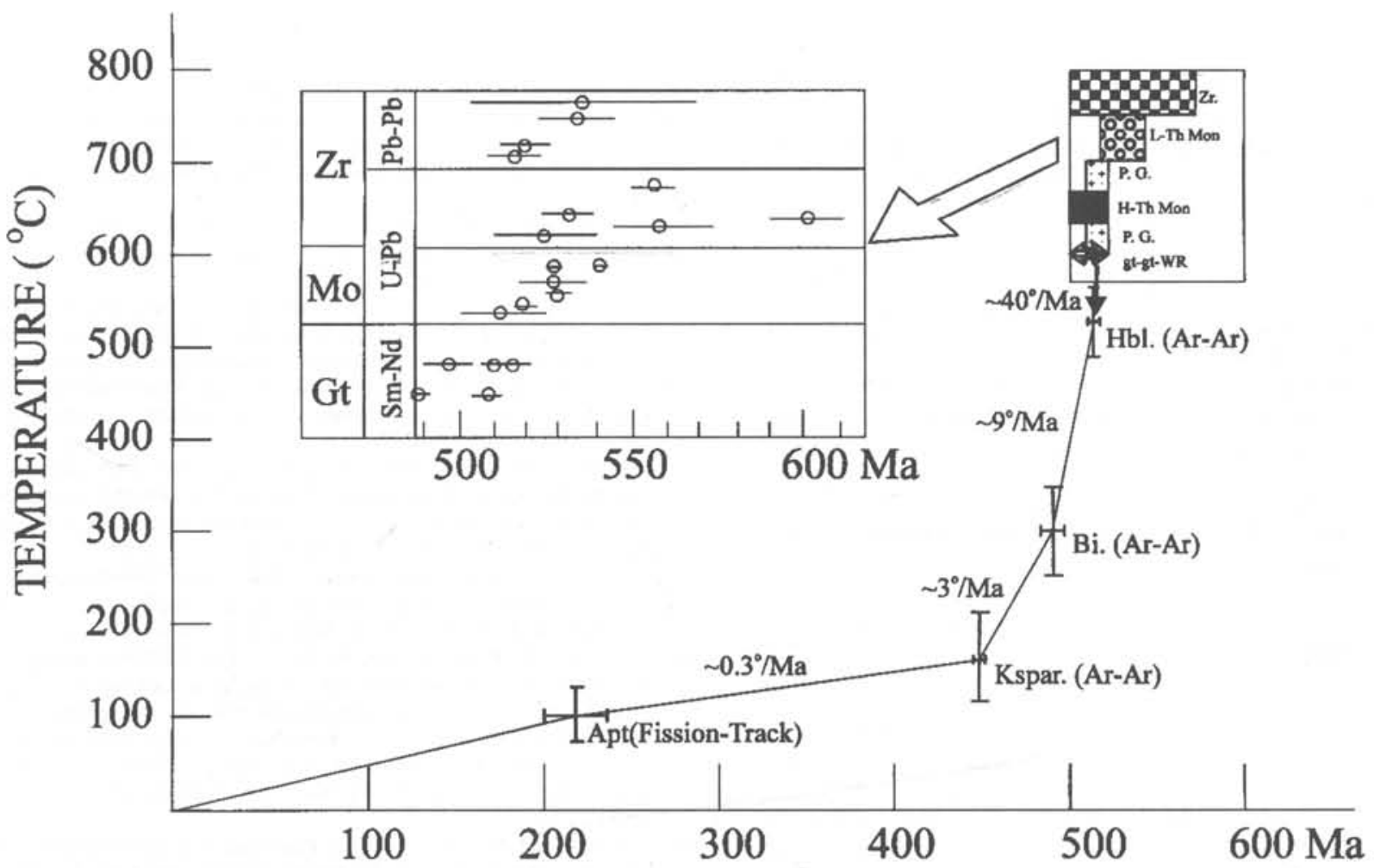

Figure 3 The cooling path for high-grade rocks of the Larsemann Hills based on thermochronological data. Details of high temperature chronological data provided by inset plot.

\section{Discussion}

The ${ }^{40} \mathrm{Ar} /{ }^{39} \mathrm{Ar}$ plateau age for hornblende at $514 \pm 2 \mathrm{Ma}$ (Sample G212-3) is close to the zircon SHRIMP U-Pb age of $516 \pm 7 \mathrm{Ma}$ for the syn-deformational Progress Granite nearby (Carson et al., 1996) and similar with Sm-Nd grt-grt-WR dates of $517 \mathrm{Ma}$ and $510 \mathrm{Ma}$ for the paragneisses from this region (Hensen and Zhou, 1995b), which implies that rapid cooling occurred around $514 \mathrm{Ma}$.

SHRIMP U-Pb dating for Sample 261 from the syn-deformational Progress Granite generally gave age results similar to those of Sample 12520 by the single zircon $\mathrm{Pb}-\mathrm{Pb}$ evaporation technique, and both methods yielded identical age results for elongated zircon grains (e.g. grain 2 and grain 5 of Sample 261, Carson et al., 1996; grain 91904 and grain 91602 of Sample 12520, Zhao et al., 1992). The technical advantage of SHRIMP U-Pb dating and its numerous analyses for one sample can give a more accurate and more reliablecrystallization age of the sample, especially a crystallization age for metamorphic rims of the zircon sample underwent high-grade metamorphism, for which the single zircon $\mathrm{Pb}-\mathrm{Pb}$ evaporation technique cannot give. In southern occurrence of the Progress Granite small pegmatitic units and thin pegmatitic intergrowths are pervasive and can develop into pegmatite dykes (Figure 1b). Fitzsimons et al. (1997) found high-Th monazite rims with younger mean ages of 518 $\pm 3 \mathrm{Ma}$ and $512 \pm 13 \mathrm{Ma}$ around low-Th cores with mean ages of $528 \pm 4 \mathrm{Ma}$ and $527 \pm 11 \mathrm{Ma}$ and attributed the high-Th monazite growth to retrograde fluid flow along the ductile shear fabric. The Progress Granite, formed at $516 \mathrm{Ma}$ and $600-700^{\circ} \mathrm{C}$, occupied a high strain zone tectonically, with dextral movement sense (Dirks et al., 1993; Carson et al., 1996). The emplacement of late N- to NWtrending planar pegmatite dykes at c. $500 \mathrm{Ma}$ (Kinny et al., 1993) demonstrates that high-grade terranes of the regions were cooling. Mylonite zones were developed along the planar pegmatite dyke margins, with the same dextral movement sense. Although the Progress Granite preserves the $\mathrm{S}_{2}$ foliation and $\mathrm{L}_{2}$ lineation identical to those of the host gneiss (Carson et al., 1996), the mineral assem- blages, which comprise $\mathrm{D}_{2}$ fabric of the host gneiss, yield estimates of c. 4.5-5.2 kbar at c. $750^{\circ} \mathrm{C}$, that is, low-pressure granulite facics condition (Stüwe and Powell, 1989a; Ren et al., 1992; Carson et al., 1997). Geochronologically the syn- $D_{2}$ Progress Granite can not be distinguished from the syn- $D_{3}$ Progress Granite within error. Both of them are of anatectic products formed in late tectonism of the early Paleozoic orogenic episode. P-T estimates for the assemblages from $\mathrm{D}_{3}$ high strain domains, host gneiss of the syn- $\mathrm{D}_{3}$ Progress Granite, also give c. $4.5-5.0 \mathrm{kbar}$ at $\mathrm{c} .750-800^{\circ} \mathrm{C}$. Therefore we consider that the Progress Granite was synchronous with $\mathrm{M}_{3}$ and $\mathrm{D}_{3}$, that $\mathrm{D}_{2}$ transpression and $\mathrm{M}_{2}$ peak metamorphism occurred around 535-541 Ma (Zhang et al., 1996; Fitzsimons et al., 1997) or slightly earlier and that the early Paleozoic orogensis of the regions could commence at c. $600 \mathrm{Ma}$ (Zhao et al., 1993, unpublished SHRIMP U-Pb data, 1997; Hensen and Zhou, 1995c).

The ${ }^{40} \mathrm{Ar} /{ }^{39} \mathrm{Ar}$ plateau age of hornblende (Sample G212-3) documents that the granulite grade terrane cooled below c. $520^{\circ} \mathrm{C}$ at $514 \pm 2 \mathrm{Ma}$ and constrains that exhumation from the middle crustal levels at a depth of 20-25 km to the upper crustal levels at a depth about $10 \mathrm{~km}$ after peak metamorphism (Carson et al., 1997) had achieved by that time. The ${ }^{40} \mathrm{Ar} /{ }^{39} \mathrm{Ar}$ plateau age of hornblende approaches the $\mathrm{Sm}-\mathrm{Nd}$ grt-grt-WR isochron ages at $517 \pm 5 \mathrm{Ma}$ and $510 \pm 5 \mathrm{Ma}$ as reported by Hensen and Zhou (1995b). The Sm-Nd grtgrt-WR isochron age can better represent the time at which the SmNd system in the garnet cooled below its $\mathrm{T}_{\mathrm{C}}$ than $\mathrm{Sm}-\mathrm{Nd}$ grt-WR and grt-mineral-WR isochron ages. The $\mathrm{T}_{\mathrm{C}}$ for the $\mathrm{Sm}-\mathrm{Nd}$ system in garnet was argued. For example, Mezger et al. (1992) proposed that the $\mathrm{T}_{\mathrm{C}}$ for the $\mathrm{Sm}-\mathrm{Nd}$ system in garnet is c. $600 \pm 30^{\circ} \mathrm{C}$, while Hensen and Zhou (1995a) suggested that, in "a memory case", it must be more than $700-750^{\circ} \mathrm{C}$. A rapid cooling rate of $\geq 40-27^{\circ} \mathrm{C} / \mathrm{Ma}$ appears reasonable after that proposed by Mezger et al.(1992) in this study (Figure 3). If we choose that suggested by Hensen and Zhou (1995a), cooling around 514 Ma would be much more rapid, at a rate $\geq 60$ $70^{\circ} \mathrm{C} / \mathrm{Ma}$. This rapid cooling can be attributed to tectonically driven exhumation along ductile shear zones active during intense early Paleozoic tectonism in the regions (Fitzsimons et al., 1997). 
Slowing of a cooling rate from c. $9^{\circ} \mathrm{C} / \mathrm{Ma}$ to c. $3^{\circ} \mathrm{C} / \mathrm{Ma}$ took place during c.500-490 Ma, when the geotherm dropped below the $\mathrm{Tc}$ for ${ }^{40} \mathrm{Ar} /{ }^{39} \mathrm{Ar}$ in biotite at c. $300^{\circ} \mathrm{C}$, and could approach a stable state. By the time when cooling below the $\mathrm{Tc}$ for ${ }^{40} \mathrm{Ar} /{ }^{39} \mathrm{Ar}$ in $\mathrm{K}$ feldspar at c. $160^{\circ} \mathrm{C}$ occurred around $554 \pm 4 \mathrm{Ma}$, erosionally controlled exhumation had been dominant.

Because of limited elevation in the Larsemann Hills, the relationship between our apatite fission track data and sampling different erosional levels cannot be demonstrated. But our apatite fission track data show that some of the samples (e.g. ZG20405, F22103) were cooled through apatite partial annealing zone (PAZ, c. $110^{\circ} \mathrm{C}-60^{\circ} \mathrm{C}$ ) rapidly at c. $210 \mathrm{Ma}$, while some of the samples (LP 20305. FQ91 and $\mathrm{O} 20211$ ) appear to have been severely to moderately annealed prior to cooling through apatite PAZ at c. $210 \mathrm{Ma}$, which supports the notion that final cooling below c. $1000^{\circ} \mathrm{C}$ during the late Paleozoic and early Mesozoic corresponded to an initial period of aborted rifting in the Lambert Garben area (Arne et al., 1993). The final cooling rate was very slow at a rate of c. $0.3^{\circ} \mathrm{C} / \mathrm{Ma}$.

\section{Conclusion}

The ${ }^{40} \mathrm{Ar} /{ }^{39} \mathrm{Ar}$ plateau age of hornblende, combined with $\mathrm{Pb}-\mathrm{Pb}, \mathrm{U}-$ $\mathrm{Pb}, \mathrm{Sm}-\mathrm{Nd}$ and ${ }^{40} \mathrm{Ar} /{ }^{39} \mathrm{Ar}$ age results published, can constrain that cooling below c. $520^{\circ} \mathrm{C}$ happened at $514 \pm 2 \mathrm{Ma}$ and that $\mathrm{c} .10-15 \mathrm{~km}$ of exhumation had achieved by that time. Rapid cooling around 514 Ma at a rate of $\mathrm{c} .40)^{\circ} \mathrm{C} / \mathrm{Ma}$ resulted from tectonically drived exhumation along the ductile shear zones. Therefore a complex cooling process with variable cooling rates could exist in the high-grade terrane due to different vertical movements in the crust during that time. Slowing of the cooling rate from c. $9^{\circ} \mathrm{C} / \mathrm{Ma}$ to c. $3^{\circ} \mathrm{C} / \mathrm{Ma}$ occurred during 500-490 $\mathrm{Ma}$, when the geotherm dropped through the closure temperature for ${ }^{40} \mathrm{Ar} /{ }^{39} \mathrm{Ar}$ system in biotite at $300^{\circ} \mathrm{C}$. Documented by an ${ }^{40} \mathrm{Ar} /{ }^{39} \mathrm{Ar}$ plateau age of K-feldspar, further change of the geotherm down below c. $160^{\circ} \mathrm{C}$ took place around $455 \mathrm{Ma}$, by which erosionally controlled exhumation had become dominant, as suggested by the very slow cooling rate at c. 3-().3" C/Ma. The final cooling through the apatite partial annealing zone happened at c. $210 \mathrm{Ma}$ and could correspond to an early period of aborted rifting in the Lambert Garben region.

\section{Acknowledgements}

This work is a contribution to IGCP project no. 368 on Proterozoic Events in East Gondwana, and is dedicated to the memory of the late Y.L. Fu, who performed the ${ }^{40} \mathrm{Ar} /{ }^{39} \mathrm{Ar}$ analyses. Logistic support by CHINARE and financial support to $Y$. Z . by the National Natural Science Foundation of China (no. 49572139) and Antarctic Adminstration of China are gratefully acknowledged.

Discussion with I. Fitzsimons and C. Carson and comments on the first draft by S. Harley aided the production of this paper.

\section{References}

Arne, D. C.. Kelly, P.R., Brown, R.W. and Gleadow. A. J. W., 1993, Reconnaissance apatite fission-track data from the East Antarctic Shield, in Findlay, R. H., Banks, M. R., Unrug. R., and Veerer. J. J. (eds). Gondwana Eight: Rotterdam. Balkema, pp.605-611.

Black, L. P., Kinny, P. D.. Sheraton, J. W. and Delor, C. P., 1991. Rapid production and evolution of late Archaean felsic crust in the Vestfold Hills of East Antarctica: Precimbrian Res., v.50, pp.283-310.

Carson, C.J., Dirks, P.H.M.G.. Hand. M.. Sims, J.P. and Wilson, C.J.L., 1995. Compessional and extentional tectonics in low-medium preessure granulites from the Larsemann Hills, East Antarctica: Geol. Mag., v.132, pp. 15I-170.

Carson,C.J.. Fanning. C.M. and Wilson, CJ.L., 1996, Timing of the Progress Granite, Larsemann Hills: additional evidence for Early Palateozoic oro- genesis within the East Antarcilc shield and implications for Gondwan: assembly: Austr. J. Earth Sci., v.43, pp.539-553.

Carson,C.J., Powell, R., Wilson, C.J.L. and Dirls, P.H.G.M., 1997, Partial melting during tectonic exhumation of a granulite terrane: an example from the Larsemann Hills, East Antarctica: J. Metamorphic Geol., v.15, pp. $105-126$

Dirks, P.H.G.M. and Wilson. C.J.L., 1995, Crust evolution of the East Antarctic mobile belt in Pryd . Bay: continental collision at 500 Ma? Precam. Res., v.75, pp. 189-207.

Dirks, P.H.G.M.. Carson. C.J. and Wilson. C.J.L., 1993, The deformational history of the Larsemann Hills, Prydz Bay; the importance of the PanAfrican (500 Ma) in East Antaretica: Antarctic Sci.. v. 5. pp.179-192.

Fitzsimons, I.C.W., 1996, Metapelitic migmatites from Brattstrand Bluffs, East Antarctica -- metamorphism, melting and exhumation of the mid crust: J. Petrol., v.37, pp.395-414.

Fitzsimons, I.C.W.. Kinny, P.D. and Harley, S.L. 1997. Two stages of zircon and monazite growth in anatectic leucogneiss: SHRIMP constraints on the duration and intensity of Pan-African metamorphism in Prydz Bay, East Antarctica:Terra Nova. v.9, pp.47-51.

Fu, Y.. Luo. X., Zhang, S. and Wang, L., 1987, ${ }^{40} \mathrm{Ar} /{ }^{39}$ Ar dating techniques and age determination of some geological samples: Bull. Inst. Geol. G.A.G.S. no.17, pp.85-107 (in Chinese with English abstract).

Fu, Y., Zhao, Y.. Wang, Y.. Liu. X., Li, J., 1993, ${ }^{+0} \mathrm{Ar} /{ }^{30} \mathrm{Ar}$ isotopic dating the biotites from the igneous and metamorphic rocks of the Zhongshan station area: Antarctic Research (English edition), v.4, pp.26-34.

Hensen, B. J. and Zhou, B., 1995a, Retention of isotopic memory in garnets partially broken down during an overprinting granulite-ficies metamorphism: Implications for the $\mathrm{Sm}-\mathrm{Nd}$ closure temperature: Geology, v.23, pp.225-228

Hensen, B. J. and Zhou, B., 1995b, A Pan-African granulite facies metamorphic episode in Prydz. Bay. Antarctica: evidence from Sm-Nd garnet dating: Austral. J. Earth Sci., v.42, pp.249-258

Hensen, B. J. and Zhou, B., 1995c. Widespread Early Paleozoic Granulite facies Metamorphism in the Prydz Bay Region. Eastern Antarctica: When did East Gondwana amalgamate? in Abstracts Volume of the 7th ISAES: University of Siena, Siena, Italy, p. 192.

Hurford. A. J. and P.F. Green, 1983, The zeta age calibration of fission track dating: Isot. Geosci., v.I. pp.285-317.

Kang. T., Zhai, P. and Feng. S.. 1990, Study of thermal history of a sedimentary basin using fission track method: Chinese Science Bulletin, v. 35. pp. 60)-62 (in chinese).

Kinny, P. D., Black, L. P. and Sheraton, J. W. 1993, Zircon ages and the dis tribution of Archaean and Proterozoic rocks in Rauer Island: Antarctic Sci., v.5, pp. 193-206.

McDougall, I. and T.M. Harrison, 1988, Geochronology and Thermochronology by the ${ }^{40} \mathrm{Ar} /{ }^{39} \mathrm{Ar}$ Method: New York, Oxford University Press, $212 \mathrm{p}$.

Mezger, K.. Essenc. E.J. and Halliday, A.H., 1992, Closure temperatures of the $\mathrm{Sm} / \mathrm{Nd}$ system in metamorphic garnets: Earth Planet. Sci. Lett., v.113, pp. 397-409.

Naeser, C.W., 1978, Fission track dating: US Geol. Surv.. Open File Rept. pp. 79-190.

Picciotto, E. and Coppes, A., 1963, Bibliographie des mesures d'ages absolus en Antarctique. Annales societe Geologique de belgique, v.85, pp. B263-308.

Ren. L., Zhao, Y., Liu, X. and Chen, T., 1992, Re-examination of the metamorphic evolution of the Larsemann Hills, East Antarctica. in Yoshida. Y., Kaminuma, K. and Shiraishi, K. (eds.), Recent Progress in Antarctic Earth Science: Tokyo, TERRAPUB, pp. 145-153.

Ravich. M. G., Klimov, M. V., and Soloviev, D. S., 1965, The Precambrian of East Antarctica. Ministry of geology, USSR, Moscow, 495p. Israel Program for scientific translations, Jerusalem (English translation, 1968).

Sheraton, J. W., Black. L. P., and McCulloch, M. T.. 1984. Regional geochemical and isotopic characteristics of high-grade metamorphics of the Prydz Bay area: the extent of Proterozoic reworking of Archaean continental crust in East Antaretica: Precambrian Res.. v.26, pp.169-198.

Steiger, R. H., and Jäger, E.. 1977, Subcommission on geochronology: Convention on the use of decay constants in geo- and cosmochronology: Earth Planet. Sci. Lett., v.36, pp.359-362.

Stiwe, K. and Powell. R., 1989a, Low-pressure granulite facies metamorphism in the Larsemann Hills. East Antarctica; petrology and tectonic implications for the evolution of the Prydz Bay area: J. Metamorphic Geol., v.7. pp.465-483.

Stüwe, K., and Powell. R., 1989b, Metamorphic segregations associated with garnet and orthopyroxene growth: 1wo examples from the Larsemann Hills, East Antarctica: Contrib. Mineral. Petrol., v. 103, pp.523-530. 
Stüwe, K., Braun, H-M., and Peer, H., 1989, Geology and structure of the Larsemann Hills area, Prydz Bay, East Antarctica: Austral. J. Earth Sci., v.36, pp.219-241.

Tingey, R.J., 1991, The regional geology of Archaean and Proterozoic rocks Antarctica, in Tingey, R.J. ed., The Geology of Antarctica: Oxford, Oxford University Press, pp.1-73.

Takingmi, Y., Funaki, M., and Tokieda, K., 1992, ${ }^{40} \mathrm{Ar} /{ }^{39} \mathrm{Ar}$ geochronological studies on some paleomagnetic samples of East Antarctica, in Yoshida, Y., Kaminuma, K., and Shiraishi, K. eds., Recent Progress in Antactic Earth Science: Tokyo, TERRAPUB, pp.61-66.

Zhang, L., Tong, L., Liu, X. and Schärer, U., 1996, Conventional U-Pb age of the high-grade metamorphic rocks in the Larsemann Hills, East Antarctica, in Pang, Z., Zhang, J. and Sun J., eds., Advances in Solid Earth Sciences: Beijing, Science Press, pp. 27-35.

Zhao, Y., Song, B., Wang, Y., Ren, L., Li, J., and Chen, T., 1991, Geochronological study of the metamorphic and igneous rocks of the Larsemann Hills, East Antarctica, in the 6th ISAES (Abs.), Tokyo: National Institute for Polar Research, Japan, pp.662-663.

Zhao, Y., Song, B., Wang, Y., Ren, L., Li, J.and Chen, T., 1992, Geochronology of the late granite in the Larsemann Hills, East Antarctica. in Yoshida, Y., Kaminuma, K., and Shiraishi, K. eds., Recent Progress in Antactic Earth Science: Tokyo, TERRAPUB, pp.155-161.

Zhao, Y., Song, B., Zhang, Z. Q., Fu, Y. L., Chen, T. Y., Wang, Y. B., Ren, L. D.,Yao,Y. P., Li, J. L. and Liu, X. H., 1993, Early Paleozoic ('Pan African')thermal event of the Larsemann Hills and its neighbours, Prydz Bay, East Antarctica. Science in China (Series B), 23: 1001-1008. (in Chinses, English edition: v.38, 74-95, 1995)
Zhao, Y., Liu, X., Song, B., Zhang, Z., Li, J., Yao, Y. and Wang, Y., 1995, Constraints on the stratigraphic age of metasedimentary rocks from the Larsemann Hills, East Antarctica: possible implications for Neoproterozoic tectonics: Precam. Res, v.75, pp.175-188.

Zhou, B. and Hensen B.J., 1992, Sm/Nd isotopis analysis of garnet: Constraints on the metamorphic history of the Prydz Bay and northern Prince Charles Mountains granulite terranes, Antarctica, in Abstracts of the application of geochronology to field related problem, Geological Society of Australia SGGMP Workshop, Alice Springs, Australia.

Zhao Yue, is Research Fellow of Geology, and Head of Antarctic and Arctic Geology Division at the Institute of Geology, Chinese Academy of Geological Sciences (CAGS). He graduated from the Changchun Institute of Geology in 1982 and completed his postgraduate study at Graduate School of CAGS in 1986. His main research interests are in Antarctic geology, especially geochronology of tectonic events in East Antarctic Craton, and tectonics of East China and adjacent areas.

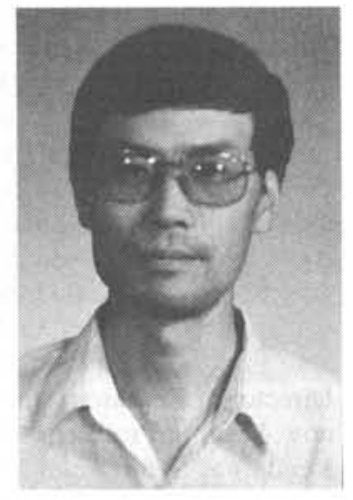

\section{Episodes is your window to the world. Subscribe today!}

\section{Episodes}

\section{Subcription Order}

Name (please print)

Address

City State/Prov.

Country Zip/Postal Code

Please begin my subscription:

$\begin{array}{llll}\text { March } & \text { June } & \text { Sept. } & \text { Dec. } \\ \text { Year } & \text { Year } & \text { Year } & \end{array}$

To start your subscription, fill in this form and mail to:

\section{Episodes}

P.O. Box 823

26 Baiwanzhuang Rd.,

Beijing 100037, China

Tel: +86-10-6832 0827; +86-10-6832 7772

Fax: +86-10-6832 8928

E-mail:episodes@public.east.cn.net igcbj@public3.bta.net.cn
Payment may be made by:

- Checks (US \$ only) made payable to Episodes

$\square$ Diners a JCB $\square$ Disa
$\square$ American Express $\square$ Mastercard

Please quote account number, expiry date and signature

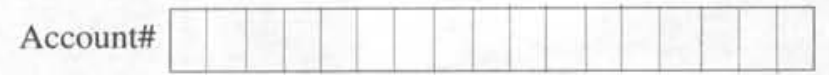

Expiry date

Signature 